\title{
24. Creating a stable Fiji
}

\section{Joni Madraiwiwi}

Two years ago, Fiji was on the threshold of having a multiparty cabinet. On that occasion, I used a Fijian saying, 'kunekunea na eloka ni dilio', to describe the rare opportunity it gave us to start afresh. The phrase is a reference to the rarity of finding the eggs of a particular bird. This is so because the bird in question actually lays its eggs in Alaska before returning to Fiji to live. We were unable to take full advantage of the moment and have since regressed. So what is it that can be done at this point to create the circumstances we so desperately seek?

There is a critical need for dialogue and engagement in fora in which the interim government and its political opponents can participate without preconditions. The National Council for Building a Better Fiji (NCBBF) can continue to develop the principles for a charter for good government. But there has to be another means for finding common ground. The onus is upon the regime, as the party holding the reins of power, to engage. Without this, the country will continue to drift, as divided and fractured as ever, with a charter and a new electoral system being imposed, and the constitution abrogated to allow the implementation of both. The implications, both internally and internationally, hardly bear thinking about. The tragedy is that many beneficial features in both the proposed charter and the electoral system would be discounted because of the manner of their implementation.

The NCBBF must proceed with haste on the drafting of the charter. Given the determination of the commander and the military to implement what emerges from the consultations, so be it. Just as Mr Qarase has said the commander must be given the benefit of the doubt in relation to a March 2009 timetable for a general election, so must we do likewise in relation to the charter. Let us see what emerges. The debate will centre on how the principles to be enshrined in the document are to be incorporated in the constitution. If the interim government wishes to force it and a new electoral system upon us, they have the backing of the military to silence dissent. But a new dispensation pushed on the people of this country will not be sustainable. In the long term, the will of the people will prevail. The 1997 constitution has been much maligned by a range of critics across the political spectrum. But it was unanimously approved by the representatives of the people of Fiji in parliament. And it was the result of one of the most concerted efforts to ascertain the views of ordinary people ever undertaken in our history.

There are mixed views about reconciliation. Who is to reconcile with whom and on what terms? Many careers and lives have been affected in the aftermath of 
5 December 2006. Those are larger issues that will have to be dealt with over the longer term. However, there are some gestures that this interim government may wish to consider as a beginning. A large number of capable and professional people were arbitrarily removed without cause from the public service and statutory corporations. Some consideration could be given to reinstatement and/or compensation - I omit those against whom the regime may have allegations and cases. Overall, a climate of unease has infected the public service and statutory corporations at all levels. There is a reluctance to take responsibility without trying to second guess our political masters. In such circumstances, prevailing uncertainties are further compounded. The result is inaction, indecision and delays that undermine the delivery of services.

The advantages of some form of dialogue in the political arena are obvious. As long as this impasse continues, economic activity will decline and significant investments not eventuate. The sanctions taken by Australia and New Zealand have had an adverse effect on initiatives to strengthen the economy. Their removal depends on the actions of the interim government. While it appears that we will have to live with the regime for some time yet, within its limited space for manoeuvre, it has some options. First, it must take a more constructive approach to the private sector. Some of the recent decisions affecting this sector have not inspired confidence. Second, the tourist industry requires more support from the authorities. As this industry provides the shortest route to generating economic growth, it requires nurturing. Third, the interim government should consider establishing mechanisms for our citizens who are leaving in numbers to work abroad. For a good portion of those it is not permanent; they fully intend to return. Remittances are now a significant source of revenue. Professor Wadan Narsey has written extensively on these issues and how the government might take advantage of the phenomenon.

We need now to begin discussions on the role of the military. Since 5 December 2006, the extent to which it has entered the public service is a concern. This has blurred the boundaries between the former, as a disciplined service, and the latter, as a civilian organization. In practical terms, this is just as critical as the drafting of the charter. It is in the military that the ever present threats of coups lie. The commitment of the present military leadership to abiding by the charter will last only their tenure in control. Their successors may have other ideas. So these issues will require sensitive handling. Because the military has come to see itself as having a part to play in national affairs, its complete return to barracks may have to be gradual. A generation of military officers has grown to maturity in the shadows of four coups. They will not be easily weaned off their appetite for more.

The courts have not fared well since 5 December 2006. The decision of the commander, as putative President, to remove the Chief Justice has served to 
exacerbate a schism in judicial ranks. An impartial and united judiciary is critical to the proper adjudication of the rights of individuals and parties - as it is when it comes to the judiciary overseeing the relationship between the state and its citizens. Yet, the apparent manner in which some of the parties have been dealt with, and the seeming partiality shown the state are matters of concern. They affect the image of the courts as the independent arbiter of rights. These issues are not raised to criticize or to compromise the standing of the courts. They are expressed in the hope that these disquieting incidents will be addressed. The divisions that have given rise to the present situation are not new. They are long standing. The acting Chief Justice, the interim Attorney-General as leader of the Bar, and the president of the Fiji Law Society have a heavy responsibility to heal the abiding fissures if lawyers are to make a positive contribution to stability.

As an attempt is made to re-establish parliamentary democracy and a more cohesive society, much will be asked of Fijian political leaders. They must demonstrate statesmanship. Quite simply, they will have to moderate the strong feelings that have been aroused in the past eighteen months. Accommodation is not be confused with surrender. The need is to find a compromise. This does not necessarily mean abandoning some of the indigenous issues that are perennial, such as the ownership of qoliqoli, and the land claims tribunal. What it does require is engagement with other communities on the issues to find some basis for settlement. It may not be possible to do so in the end, but a concerted effort has to be made.

The lack of Fijian participation in the commercial and private sector remains a concern. This perceived disadvantage provides fertile ground for exploitation by extremists. The business community must take up the responsibility of mentoring Fijians in a more visible and organized manner. At the same time, Fijians have an ambivalent attitude towards business and commerce. While wishing to participate, they are reluctant to abandon the costly rituals and obligations that are such a part of Fijian social life. Fijian leaders in the vanua, church and politics must attempt to create an enabling environment, so that the more enterprising among us are not perpetually torn between those conflicting demands. Those that achieve some success often find they are burdened with a plethora of obligations from less fortunate kin. Rusiate Nayacakalou, the brilliant Fijian anthropologist, remarked on this over four decades ago and we still face the same dilemmas.

In a multicultural and multireligious society like ours, religious leaders play a significant part. They are also respected figures. However, ethnic differences are reinforced by the religious divide. I accept that many Christian leaders and their flock are uncomfortable dealing with their Hindu and Muslim brothers and sisters at a religious level. The interfaith group has found the journey a lonely one. But it is surprising that there has been little interaction on community 
concerns. Issues like the desecration of temples, the plight of the poor, HIV/AIDS, youth suicides, and teenage pregnancies could be considered and resources pooled. In Samoa, the churches have taken a very enlightened approach to the twin concerns of HIV/AIDS and youth suicides. It would convey powerful messages to the community. The gulf that prevails on theological principles ought not to preclude cooperation at this level.

Some would decry the persistence of ethnically based institutions in the education system. However, I am more concerned that more has not been done to inculcate a sense of citizenship in our schools and colleges. This must begin in preschool and kindergarten and continue until seventh form. Education is not only about preparing the next generation for the workplace: It is also, equally, about shaping the society of which it will be part. The teaching of Fijian and Hindi must necessarily be part of this development. There is an argument that this is irrelevant, as English is the language of international commerce and trade. But in local circumstances, it will create more opportunities for dialogue in terms communities find easier to relate to.

Civil society plays a positive role by providing a voice for the marginalized. This process must proceed apace. Creating a human rights culture is critical. Where the people of Fiji are more aware of the connections between their rights and good government, it emboldens them. In the end, the constitution, the charter and human rights treaties are just pieces of paper with words on them. The challenge is to build in the people of this country an awareness that they themselves are the best defenders of those rights. In the event that anyone seeks to take them away, they must use either the courts or peaceful civil action to defend them. They cannot be taken for granted.

There are no instant solutions to the challenges that face us. But as long as the contending parties are willing to engage in open and honest dialogue, we can begin to deal with them. It requires patience, forbearance, humility and goodwill to deal with the issues that divide. It also calls for maturity. Without this, the country will continue to drift and resentment will foster. Placing preconditions serves little purpose other than to maintain the impasse. There is a certain weariness among the ordinary people of this country. They want some resolution to the stalemate. Barking at each other and point-scoring does not advance matters further. Low levels of economic growth, collapsing infrastructure, the land tenure issue, poverty and squatters require the attention of a government that has the backing of the entire community. What needs to be done is clear. Do we have the wherewithal, the courage and the imagination to do it? The metaphorical search for the eggs of the dilio bird does not have to take us to Alaska, because the solutions lie in our midst. 